\title{
Bidentate Lactate Binding to La(III)-Cu(II) Metallacrown with L-Phenylalaninehydroximate Ligands: the Chiral Separation of L-Lactate
}

\author{
Marina A. Katkova, ${ }^{\circledR}$ Evgeny V. Baranov, Galina S. Zabrodina, \\ and Sergey Yu. Ketkov \\ G.A. Razuvaev Institute of Organometallic Chemistry of RAS, 603905 Nizhny Novgorod, Russia \\ @Corresponding author E-mail: marina@iomc.ras.ru
}

\begin{abstract}
The chiral La(III)-Cu(II) metallacrown bearing L-phenylalaninehydroximate ligands was probed for complexation towards racemic lactate. X-Ray diffraction analysis revealed the bidentate chelation of L-lactate in the solid state to form enantiopure crystals. L-Phenylalaninehydroximate La(III)-Cu(II) metallacrown showed, therefore, a strong preference for coordination of the L-type lactate providing the chiral separation of the target compound.
\end{abstract}

Keywords: Metallacrown, phenylalaninehydroximate, lanthanum, copper, chirality, lactate, X-ray structure.

\section{Бидентатное присоединение лактата к La(III)-Cu(II) металлакрауну с L-фенилаланингидроксиматными лигандами: хиральное отделение L-лактата}

\author{
М. А. Каткова, ${ }^{@}$ Е. В. Баранов, Г. С. Забродина, С. Ю. Кетков \\ Институт металлоорганической химии им. Г.А. Разуваева РАН, 603950 Нижний Новгород, Россия \\ ${ }^{\circledR}$ E-mail: marina@iomc.ras.ru
}

\begin{abstract}
Хиральный металлакраун La(III)-Cи(II), полученный из L-фенилаланингидроксиматных лигандов, исследовали на комплексообразование с рацемическим лактатом. Рентгеноструктурный анализ выявил бидентатное хелатирование L-лактата в твердом состоянии с образованием кристаллов энантиочистого комплекса. Таким образом, L-фенилаланингидроксимат La(III)-Cu(II) присоединяет только лактат L-типа, обеспечивая хиральное разделение иелевого соединения.
\end{abstract}

Ключевые слова: Металлакраун, фенилаланингидроксимат, лантан, медь, хиральность, лактат, РСА.

The chiral structures are important features of functional molecules and materials of living matter and nature. Macrocycles have shown great utility in the design of chiral synthetic receptors, enabling the development of highly preorganized structures. The molecular design of such synthetic hosts determines the efficiency and selectivity of molecular recognition in chemical and biological systems, especially in aqueous solution. ${ }^{[1]}$ Among macrocycles, metallacrowns have become an exceptional class due to their facile synthetic approach to prepare chiral compounds that can form face differentiated structures. ${ }^{[2]}$ In particular, 15-MC-5 compounds formed with L-R-amino hydroximates, copper(II) as the ring metal ion and lanthanide(III) as the center ion should position each side chain on one side of the planar metallacrown. If the $\mathrm{Cu}-\mathrm{N}-\mathrm{O}-\mathrm{Ln}$ connectivity for the molecules has the same directionality as L-amino hydroximate ligand, then the opposite face of the metallacrown has been differentiated, when D-amino hydroximate is used..$^{[3]}$ Using this design concept, we have prepared metallacrown $\mathrm{La}\left(\mathrm{H}_{2} \mathrm{O}\right)_{4}\left[15-\mathrm{MC}_{\mathrm{Cu}(\mathrm{II}) \text { Pheha }}-5\right] \mathrm{Cl}_{3}$ based on L-phenylalanine 

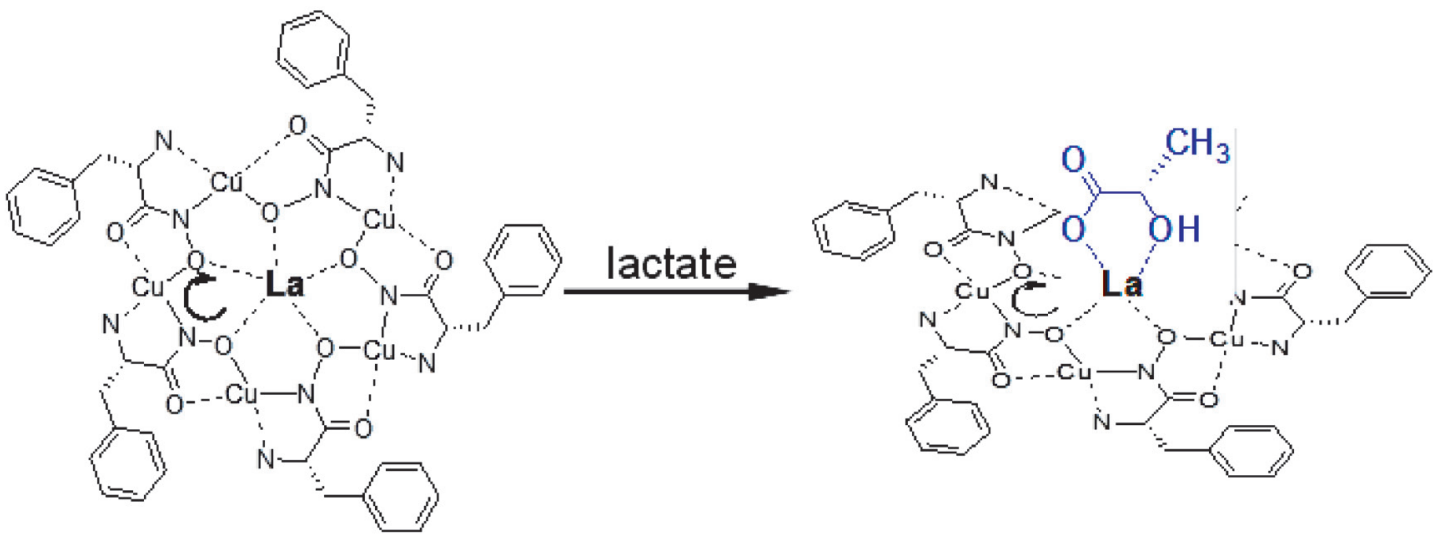

Scheme 1. Schematic representation of the synthesis of complex 1. Hydrogen atoms and solvate molecules are omitted for the sake of simplicity.

hydroxamic acid according to synthetic procedure reported earlier. ${ }^{[4]}$ Following addition of 2.5 equivalents of racemic lactate to $\mathrm{La}\left(\mathrm{H}_{2} \mathrm{O}\right)_{4}\left[15-\mathrm{MC}_{\mathrm{Cu}(I I) \text { Pheha }}-5\right] \mathrm{Cl}_{3}$ affords the crystalline product $\mathbf{1}$ in high yield $\$$ (Scheme 1).

This process involves a displacement of lanthanidebound water molecules by the lactate ligand in aqueous conditions. Note, that examples of chiral anion binding to welldefined metal complexes in water are of considerable current interest. ${ }^{[5]}$ The chelation of the ligand to lanthanide(III) centers verified by X-ray studies attracts enhanced attention. Lactate was selected as a representative ubiquitous organic molecule that exists in nearly all biological systems like microorganisms, plants and animals. L-Lactate is one of the most important biomarkers for a variety of physiological disorders.

A single crystal X-ray diffraction analysis (SC-XRD) has been performed to establish the molecular and crystalline structure of complex 1 (Figure 1, Table 1). According to the XRD investigations, ${ }^{\#}$ complex $\mathbf{1}$ consists of the lanthanum $15-\mathrm{MC}_{\mathrm{Cu}(I I) \text { Pheha }}-5$ moiety, one lactate molecule, two
Table 1. Selected bond lengths $(d)$ for complex 1 .

\begin{tabular}{lc}
\hline \multicolumn{1}{c}{ Bond } & $d, \AA$ \\
\hline $\mathrm{La}(1)-\mathrm{O}$ (oxime) & $2.489(2)-2.592(2)$ \\
$\mathrm{La}(1)-\mathrm{O}$ (water) & $2.581(3), 2.532(2)$ \\
$\mathrm{La}(1)-\mathrm{O}($ lactate) & $2.531(2), 2.620(2)$ \\
$\mathrm{Cu}-\mathrm{O}(15-\mathrm{MC}-5)$ & $1.905(2)-1.950(2)$ \\
$\mathrm{Cu}-\mathrm{N}(15-\mathrm{MC}-5)$ & $1.892(3)-2.043(3)$ \\
$\mathrm{Cu}-\mathrm{Cl}$ & $2.728(1), 2.843(1)$ \\
$\mathrm{Cu}-\mathrm{O}($ water $)$ & $2.706(3)$ \\
\hline
\end{tabular}

chlorine anions and 8.25 water molecules. The lanthanum atom $\mathrm{La}(1)$ is disposed at the center of the metallacrown and bound to its five oxygen atoms $\mathrm{O}(1,3,5,7,9)$ in the equatorial plane. The $\mathrm{La}(1)$ cation additionally binds one lactate and two water molecules which are located at the apical positions of the lanthanum coordination environment.
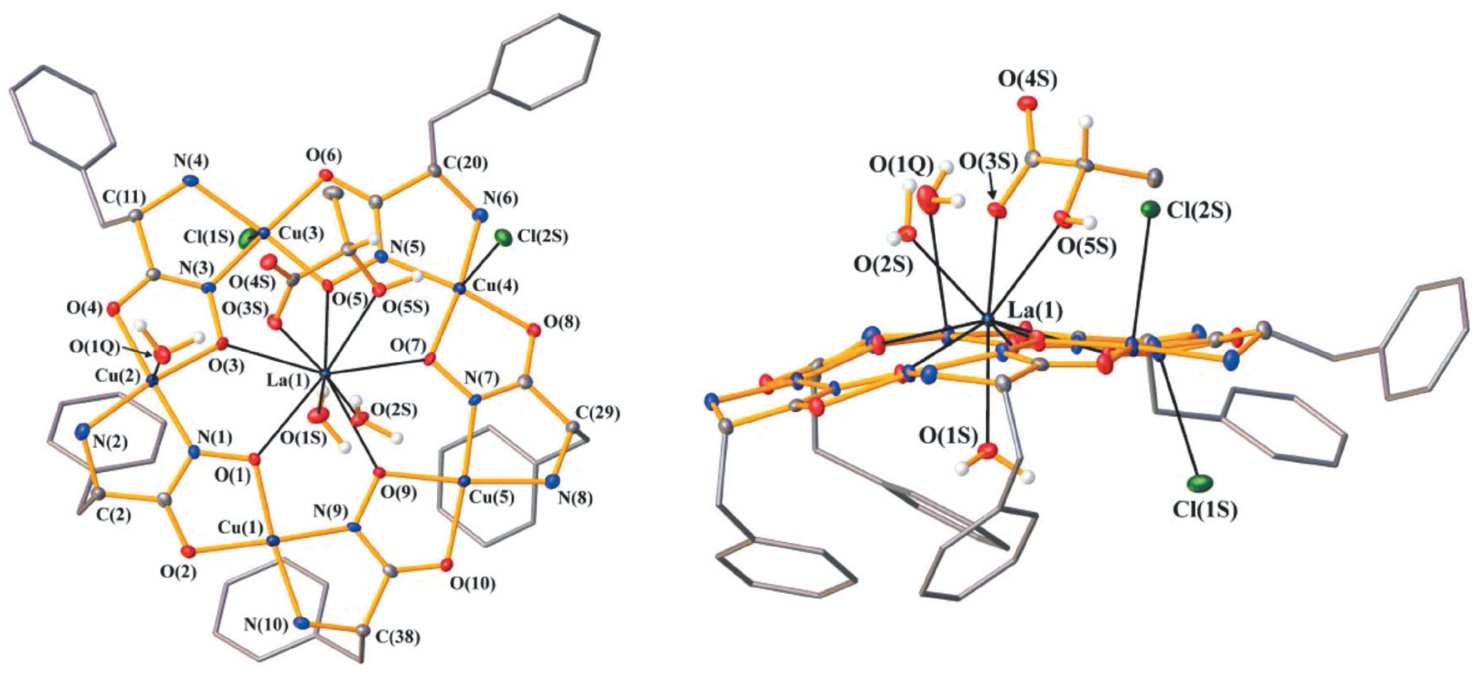

Figure 1. Top and side views of the structure of complex 1. Thermal ellipsoids are drawn at the $50 \%$ probability level. $\mathrm{PhCH}_{2}$-substituents are depicted in a wireframe style for the purpose of clarity. $\mathrm{H}$ atoms in the 15-MC-5 metallacrown and in the lactate Me-group as well as all uncoordinated solvate $\mathrm{HOH}$ molecules are omitted. 
The lactate molecule coordinated in a bidentate fashion via the $\mathrm{O}(3 \mathrm{~S})$ and $\mathrm{O}(5 \mathrm{~S})$ atoms occupies the upper apical site of lanthanum together with one water molecule $(\mathrm{O}(2 \mathrm{~S})$ atom $)$, whereas another water molecule $(\mathrm{O}(1 \mathrm{~S})$ atom) is located at the opposite apical position.

The copper metallacrown ring is not flat and has a subtle wavy shape. The mean deviation of non-hydrogen atoms of the copper-crown moiety from the plane is $0.25 \AA$. The lanthanum atom $\mathrm{La}(1)$ rises above the plane of the copper metallacrown ring by $0.79 \AA$ towards the lactate ligand. Displacement of the $\mathrm{La}(1)$ atom from the least-square plane of five hydroxamate oxygen atoms is $0.63 \AA$. As a consequence the sum of angles $\mathrm{O}-\mathrm{La}(1)-\mathrm{O}$ in the basal plane equals to $349.5^{\circ}$. The angles between the upper and lower apical atoms $\mathrm{O}(2,3,5 \mathrm{~S})-\mathrm{La}(1)-\mathrm{O}(1 \mathrm{~S})$ are in the range of $131.97(8)-148.23(8)^{\circ}$. The bite angle of the lactate molecule is $59.32(7)^{\circ}$. The chlorine anions are coordinated at the $\mathrm{Cu}(3)$ and $\mathrm{Cu}(4)$ atoms. In addition, the water molecule with the atom $\mathrm{O}(1 \mathrm{Q})$ is bound to $\mathrm{Cu}(2)$. Thus the copper atoms $\mathrm{Cu}(2-4)$ are square-pyramidal wherein the coordinated chlorine anions and water molecule occupy apical positions. It should be noted that two atoms of chlorine are oppositely located relative to the metallacrown plane. A detailed analysis of the molecular structure of complex $\mathbf{1}$ has revealed that the $\mathrm{PhCH}_{2}$-substituents are folded under the plane of the copper metallacrown ring, where only one water mol- ecule coordinated to lanthanum is located. However, the $\mathrm{Ph}$ rings of these substituents are differently oriented. Thus, the phenyl rings of three $\mathrm{PhCH}$-substituents at the $\mathrm{C}(2)$, $\mathrm{C}(29)$ and $\mathrm{C}(38)$ atoms are completely under the metallacrown plane, shielding the lower axial positions of the $\mathrm{Cu}(2)$, $\mathrm{Cu}(5)$ and $\mathrm{Cu}(1)$ atoms, respectively. The other two $\mathrm{Ph}$ rings of the substituents at the $\mathrm{C}(11)$ and $\mathrm{C}(20)$ atoms are disposed outside the boundaries of the metallacrown. Obviously, this is due to the fact that in the case of the $\mathrm{PhCH}_{2}$ substituent at the $\mathrm{C}(11)$ atom, the lower axial position of the $\mathrm{Cu}(3)$ atom is occupied by the coordinated $\mathrm{Cl}(1 \mathrm{~S})$ anion. And in the region of the upper apical position of the $\mathrm{Cu}(3)$ atom, free from coordinated molecules, there is a methyl group of the lactate molecule. It was found that the second (lower) apical position of the $\mathrm{Cu}(4)$ atom is not occupied. However, the Ph-ring of the substituent at the $\mathrm{C}(20)$ atom does not obscure the lower axial position of the $\mathrm{Cu}(4)$ atom, and this is due to the presence of a T-shaped stacking of the Ph-ring with hydrogen of the solvate water molecule in the crystal.

Thus, in the molecule of complex 1 with a squarepyramidal configuration of $\mathrm{Cu}(2-4)$ copper atoms, their second axial position remains free (as in the case of the $\mathrm{Cu}(4)$ atom), or is additionally shielded by the Me-substituent of lactate (in the case of the $\mathrm{Cu}(3)$ atom) or by the $\mathrm{Ph}$ ring of the $\mathrm{PhCH}_{2}$ substituent (in the case of the $\mathrm{Cu}(2)$ atom). The coordination environment of the $\mathrm{Cu}(1)$ and $\mathrm{Cu}(5)$ atoms

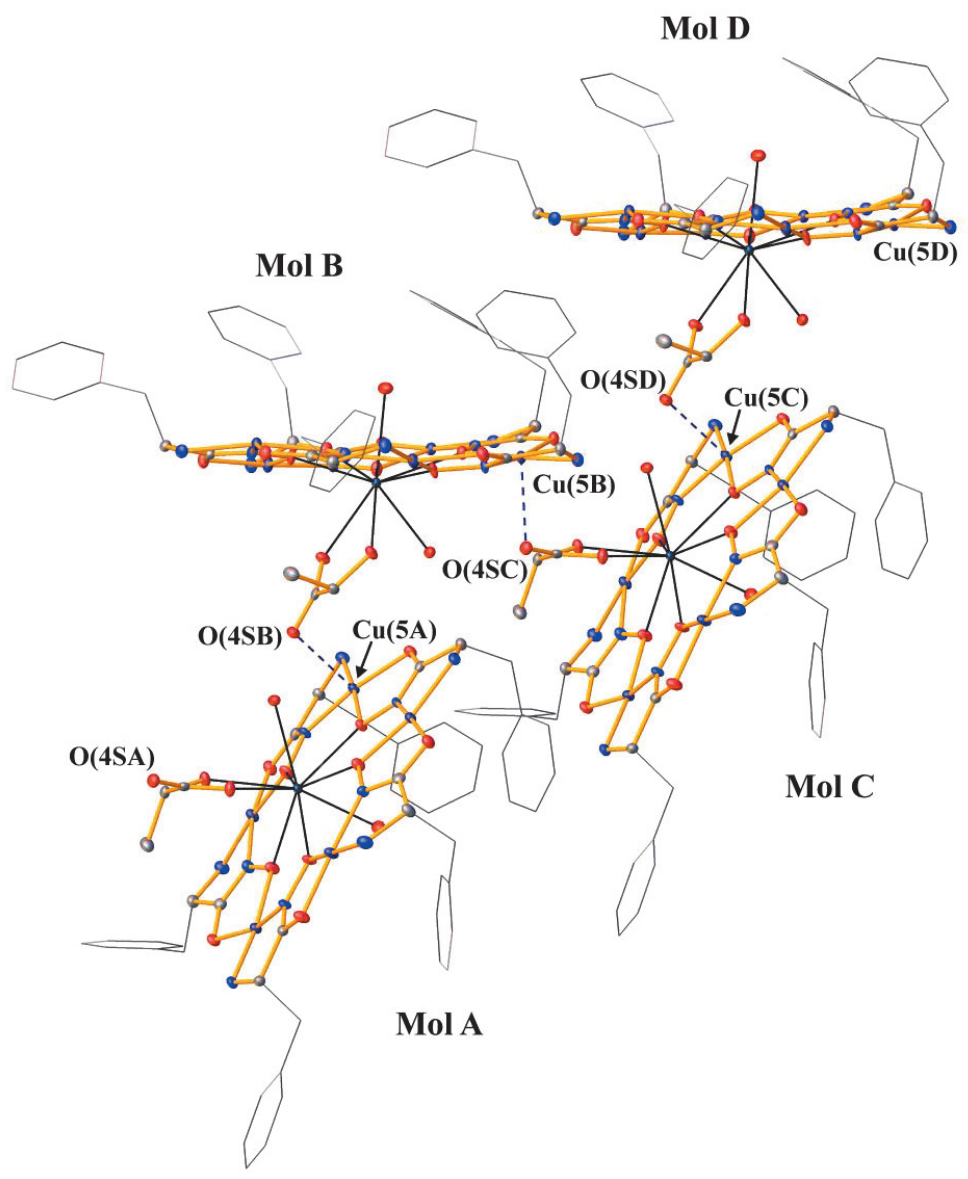

Figure 2. Fragment of the crystal packing of 1 . The intermolecular interactions $\mathrm{Cu}(5) \ldots \mathrm{O}(4 \mathrm{~S})$ are shown. Thermal ellipsoids are drawn with a $50 \%$ probability. $\mathrm{PhCH}_{2}$ substituents are depicted in the wireframe style. All solvate water molecules as well as water molecules with chlorine ions coordinated at $\mathrm{Cu}$ atoms are omitted for clarity. 
has a planar-square configuration. In the area of their lower apical position the $\mathrm{Ph}$ rings of the $\mathrm{PhCH}_{2}$ substituents are located. An analysis of the crystal packing of complex 1 showed that there is an intermolecular contact between the $\mathrm{Cu}(5)$ and $\mathrm{O}(4 \mathrm{~S})$ atoms of neighboring molecules. The second oxygen atom $\mathrm{O}(4 \mathrm{~S})$ of the carboxylate group of lactate participates in the intermolecular interaction with the neighboring molecule of the complex via the $\mathrm{Cu}(5)$ atom at a distance of 2.528(3) $\AA$, which is noticeably shorter than the coordination bond $\mathrm{Cu}(2) \ldots \mathrm{O}(1 \mathrm{Q})^{\mathrm{HOH}}(2.706(3) \AA)$. Thus, due to the intermolecular $\mathrm{Cu}(5) \ldots \mathrm{O}(4 \mathrm{~S})$ interaction, a zigzag chain of molecules of complex $\mathbf{1}$ is formed along the $a$ axis (Figure 2) and the coordination environment of $\mathrm{Cu}(5)$ becomes pyramidal-square. In the crystal of complex $\mathbf{1}$ the methyl substituent of lactate is turned in the opposite direction from the intermolecular contact $\mathrm{Cu}(5) \ldots \mathrm{O}(4 \mathrm{~S})$. Based on analysis of the crystal packing, it becomes obvious that the mutual arrangement of neighboring molecules Mol A, Mol B, Mol C...etc. in the zigzag chain is in accordance with the preferable coordination of the L-lactate molecule.

In conclusion, we have elucidated unique interaction between chiral 15-MC-5 metallacrown and racemic lactate that enables the formation of enantiopure crystals where L-lactate is bound to the central atom of the $\mathrm{La}$ (III)- $\mathrm{Cu}(\mathrm{II})$ L-phenylalaninehydroximate metallacrown as a bidentate ligand. The possible mechanisms of this effect are under investigation. The results reported in this work demonstrate prospects of the application of metallacrowns for separation of chiral mixtures and form a basis of new homochiral approaches to crystal engineering.

Acknowledgements. This research was funded by the Russian Science Foundation (project No.18-1300356). The experimental investigation was carried out using the equipment of "Analytical Center of the IOMC RAS" in G.A. Razuvaev Institute of Organometallic Chemistry RAS with the financial support of the Federal objective program "Research and development in priority directions of advancement of science and technology complex of Russia for 2014-2020" (Unique project identifier is RFMEFI62120X0040).

\section{References and Notes}

$\dagger \quad X$-Ray data collection and structure refinement. The measurements were made on a Bruker D8 Quest diffractometer with a CMOS area detector and a microfocus tube source (Mo-K $\alpha$ radiation, $\lambda=0.71073 \mathrm{~A}, \omega$ - and $\varphi$-scanning). The semi-empirical method SADABS ${ }^{[6]}$ was applied for the absorption correction. The structure was solved by dual-space method using the SHELXT ${ }^{[7]}$ software and refined by the full-matrix leastsquares technique against $F^{2}$ with the anisotropic displacement parameters for all non-hydrogen atoms. The hydrogen atoms in the 15-MC-5 metallacrown and at the lactate carbon atoms were placed geometrically and included in the structure factors calculation in the riding motion approximation. The $\mathrm{H}$ atoms at the oxygen atoms of water and lactate mol- ecules were found from Fourier syntheses of electron density and were refined isotropically with $U_{\text {iso }}(\mathrm{H})=1.2 U_{\text {eq }}$. All the data reduction and further calculations were performed using the SAINT ${ }^{[8]}$ and SHELXTL ${ }^{[9]}$ packages. The figures of structure 1 were drawn using the OLEX2 software. ${ }^{[10]}$ CCDC reference number is 2024419. The data can be obtained free of charge from the Cambridge Crystallographic Data Centre at www.ccdc.cam.ac.uk/data_request/cif.

$\S$ All chemicals were reagent-grade and were used as received from Sigma Aldrich without further purification. Complex $\mathrm{La}($ lactate $)\left(\mathrm{H}_{2} \mathrm{O}\right)\left[15-\mathrm{MC}_{\mathrm{Cu}(\mathrm{II}) \text { Phalaha }}-5\right](\mathrm{Cl})_{2}$ (1) was prepared by addition of 2.5 equivalents of racemic lactate to $\mathrm{La}\left(\mathrm{H}_{2} \mathrm{O}\right)_{4}\left[15-\mathrm{MC}_{\mathrm{Cu}(\mathrm{II}) \text { Pheha }}-5\right] \mathrm{Cl}_{3}(1 \mathrm{mmol})$ in water. The solution was filtered off and left to evaporate slowly. After two days the blue plate crystals of 1 formed. Yield: $83 \%$. Found: C 34.85, H 4.40, N 8.41\%. $\mathrm{C}_{48} \mathrm{H}_{71.50} \mathrm{Cl}_{2} \mathrm{Cu}_{5} \mathrm{LaN}_{10} \mathrm{O}_{21.25}$ requires C 34.81, H 4.35, N 8.46, La 8.39.

\# Crystal data for $\mathbf{1}\left(\mathrm{C}_{48} \mathrm{H}_{71.5} \mathrm{Cl}_{2} \mathrm{Cu}_{5} \mathrm{LaN}_{10} \mathrm{O}_{21.25}\right)$. Crystal system Orthorhombic, $\mathrm{T}(\mathrm{K})$ 100(2), space group P2(1)2(1)2(1), $\mathrm{a}=12.6300(8), \mathrm{b}=20.1455(14), \mathrm{c}=24.2138(15) \AA, \alpha=90$, $\beta=90, \gamma=90 . \mathrm{V}=6160.9(7) \AA^{3}, \mathrm{Z}=4, \mathrm{~F}(000)=3342, \rho_{\text {calc }}$ $1.786 \mathrm{~g} \cdot \mathrm{cm}^{-3}, \mu 2.541 \mathrm{~mm}^{-1}$, total reflections 51179 , independent reflections 14799. $R_{l} / w R_{2}(\mathrm{I}>2 \sigma(\mathrm{I})) \quad 0.0233 / 0.0480$, $R_{1} / w R_{2}$ (all data) $0.0259 / 0.0485$, GOF on $F^{2} 1.023$.

1. a) Gropp C., Quigley B.L., Diederich F. J. Am. Chem. Soc. 2018, 140, 2705-2717; b) Zhong D.C., Lu T.B. Chem. Commun. 2016, 52, 10322-10337.

2. a) Bodwin J.J., Cutland A.D., Malkani R.G., Pecoraro V.L. Coord. Chem. Rev. 2001, 216-217, 489-512; b) Mezei G., Zaleski C.M., Pecoraro V.L. Chem. Rev. 2007, 107, 4933-5003; c) Tegoni M., Remelli M. Coord. Chem. Rev. 2012, 256, 289-315; d) Happa P., Plenka C., Rentschler E. Coord. Chem. Rev. 2015, 289-290, 238-260; e) Ostrowska M., Fritsky I.O., Gumienna-Kontecka E., Pavlishchuk A.V. Coord. Chem. Rev. 2016, 327-328, 304-332; f) Katkova M.A. Russ. J. Coord. Chem. 2018, 44, 284-300.

3. a) Stemmler A.J., Barwinski A., Baldwin M.J., Young V., Pecoraro V.L. J. Am. Chem. Soc. 1996, 118, 11962-11963; b) Katkova M.A., Zabrodina G.S., Zhigulin G.Yu., Rumyantsev R.V., Ketkov S.Yu. Russ. J. Coord. Chem. 2019, 45, 721-727.

4. a) Makarov S.G., Zabrodina G.S., Cherkasov A.V., Plyusnin P.E., Arapova A.V., Katkova M.A., Ketkov S.Yu. Macroheterocycles 2016, 9, 263-267; b) Zabrodina G.S., Katkova M.A., Samsonov M.A., Ketkov S.Yu. Z. Anorg. Allg. Chem. 2018, 644, 907-911; c) Katkova M.A., Zabrodina G.S., Baranov E.V., Muravyeva M.S., Kluev E.A., Shavyrin A.S., Zhigulin G.Yu., Ketkov S.Yu. Appl. Organomet. Chem. 2018, 32, e4389; d) Katkova M.A., Zabrodina G.S., Rumyantcev R.V., Zhigulin G.Yu., Ketkov S.Yu., Lyssenko K.A., Fomina I.G., Eremenko I.L. Eur. J. Inorg. Chem. 2019, 2019, 4328-4335.

5. Staszak K., Wieszczycka K., Marturano V., Tylkowski B. Coord. Chem. Rev. 2019, 397, 76-90.

6. Sheldrick G.M. SADABS v.2016/2, Bruker/Siemens Area Detector Absorption Correction Program, Bruker AXS, Madison, Wisconsin, USA. 2016.

7. Sheldrick G.M. Acta Cryst. 2015, A71, 3-8.

8. Bruker. SAINT Data Reduction and Correction Program v. 8.38 A, Bruker AXS, Madison, Wisconsin, USA. 2017.

9. Sheldrick G.M., SHELXTL. Version 6.14. Structure Determination Software Suite; Madison (WI, USA): Bruker AXS, 2003.

10. Dolomanov O.V., Bourhis L.J., Gildea R.J., Howard J.A.K., Puschmann H. J. Appl. Cryst. 2009, 42, 339-341. 